\title{
Effect of age, impaction types and operative time on inflammatory tissue reactions following lower third molar surgery
}

Seidu A Bello ${ }^{1 *}$, Wasiu L Adeyemo ${ }^{2 \dagger}$, Babatunde O Bamgbose ${ }^{3+}$, Emeka V Obi ${ }^{1 \dagger}$ and Ademola A Adeyinka ${ }^{1 \dagger}$

\begin{abstract}
Background: Postoperative mobidity following third molar surgery is affected by a number of factors. The study of these factors is essential for effective planning and limitation of morbidity. The aim of this study was to determine the effect of age, type of impaction and operative time on immediate postoperative tissue reactions following mandibular third molar surgery.

Methods: Consecutive patients with impacted mandibular third molar teeth were studied. All the third molars were classified according to Winter's classification. Surgical extraction was performed on all the patients by a single surgeon under local anaesthesia. The operation time was determined by the time lapse between incision and completion of suturing. Postoperative pain, swelling and trismus were evaluated.

Results: There were 120 patients with an age range of 19-42 years. Patients in the age range of 35-42 years recorded a lower pain score $(p=0.5)$ on day 1 . The mouth opening was much better in the lower age group on day 2 and 5 ( $p=0.007$ and $p=0.01$ respectively). Pain, swelling and trismus increased with increasing operative time. Distoangular impaction was significantly associated with higher VAS score on day 1 and 2 ( $p=0.01,0.0,04$ ). Distoangular and horizontal impaction are associated with a higher degree of swelling and reduced mouth opening on postoperative review days. Vertical impaction was associated with the least degree of facial swelling and best mouth opening.
\end{abstract}

Conclusions: Increasing operating time and advancing age are associated with more postoperative morbidity, likewise distoangular and horizontal impaction types.

\section{Background}

The quality of life experienced by patients following third molar surgery is increasingly becoming a health concern [1]. Third molar surgeries are associated with unpleasant experience by the patients, referred to as postoperative morbidity, which could be divided into immediate postoperative tissue reactions and complications $[2,3]$. The immediate postoperative tissue reactions are characterized by pain, swelling, trismus and dysphagia [4]. Pain, swelling and trismus are normal reactions following third molar surgery and are frequent indices

\footnotetext{
* Correspondence: sabello2004@yahoo.com

+ Contributed equally

'Department of Dental \& Maxillofacial Surgery, State House Medical Centre, Asokoro, Abuja, Nigeria

Full list of author information is available at the end of the article
}

of researches both in the methodology of the surgery and the pharmacology of drugs used [5].

Factors affecting postoperative morbidity could be patient factors, tooth related factors and operative factors [6]. Patient factors include age, sex, size or build, ethnic background, smoking, contraceptives and oral hygiene [7]. Tooth related factors include existing infection (pericoronitis), type of impaction, depth of impaction, relationship to inferior alveolar nerve, density of surrounding bone and associated pathology like cyst or neoplasm [8]. The operative factors include the use of drugs, type and extent of incision, wound closure technique, surgeons experience and duration of operation $[9,10]$. Winter's classification [11] of impacted third molar is based on its orientation to an imaginary line passing through the occlusal surfaces of first and second molars to the retromolar areas as seen on a periapical

\section{Biomed Central}


radiograph (or an orthopanthomograph) [12]. The impactions are classified into horizontal, mesioangular, vertical, distoangular, buccolingual and ectopic. Pell and Gregory [13] similarly classified spatial relationship of impacted third molar into vertical, horizontal, inverted, mesioangular and distoangular.

The surrounding bone in young patients is relatively soft and more resilient compared to older patients, where the bone is harder, necessitating more bone removal, with more difficulty in separating tooth from bone, resulting in more postoperative pain, swelling and trismus [2,14]. Bruce et al, [15] while investigating the role of age on postoperative morbidity associated with mandibular third molar, found that the patients above 35 years recorded more swelling and trismus. Duration of surgery is an operative factor that has been found to influence the immediate postoperative factors following impacted third molar surgery. Definition of operating time varies among different reports. Akinwande [16] defined this as the time lapse between the beginnings of bone drilling to the end. Raprastikul et al [17] on the other hand defined it as the time lapse between incision and completion of suturing. A range of 11.03 minutes to 25.0 minutes has been reported in the literatures [16,17]. Age of patients, type of impaction and duration of operation have been mentioned in scientific literatures as factors that influence the immediate postoperative reactions following third molar surgery but objective assessment are lacking. This study aims to determine the effect of these factors on pain, swelling and trismus following mandibular third molar surgeries.

\section{Patients and Methods}

Consecutive patients scheduled to undergo surgical removal of impacted mandibular third molars in the Maxillofacial Surgery Unit of State House Medical Centre, Abuja, Nigeria from February to November 2009, were recruited into the study. Clearance was obtained from the Ethics and Privileges Committee of the hospital and informed consent was signed by the patients before enrolment. Smokers, patient with systemic diseases and patients with active pericoronal lesions were excluded from the study. Orthopantomographic images were used to classify all the impacted mandibular third molars into Mesioangular, Distoangular, Vertical and Horizontal impactions based on Winter's classification.

Surgical extraction of a tooth per session was performed on all the patients by the same surgeon under local anaesthesia. For the patients that required bilateral extraction, a gap of at least 15 days was allowed between the two procedures to allow for total recovery from the first one. Access was gained through a 3-sided mucoperiosteal flap and ostectomy was carried out with a fissure bur and normal saline irrigation. With adequate ostectomy, elevation of the tooth was carried out and was followed by socket toileting. Sectioning of the tooth was carried out whenever necessary. They were then discharged home with standard postoperative instructions.

The operation time was determined by the time lapse between incision and completion of suturing. They were all placed on broad spectrum antibiotics and analgesics of diclofenac Potassium (cataflam Novartis) $50 \mathrm{mg} 8$ hourly for 3 days.

Postoperative pain, swelling and trismus were evaluated. Pain was estimated subjectively by asking the patient to rate the nociceptive experience on a visual analog scale of 0 to 5 . The leaflets were handed over to them for daily entry with day 1 being the operation day and the assessment was done for 7 days.

Swelling was assessed by a modification of a 3 line measurements (Figure 1) using 5 fixed points on surgical side of the face and finding the average. (Ustun $\mathrm{Y}$, Erdogan O, Esen E, Karshi E. Comparison of the effects of 2 doses of methylprednisolone on pain, swelling and trismus after third molar surgery Oral Surg Oral Med Oral Pathol Oral Radiol Endo 2003; 96: 535-539). The fixed points used were $A$; the most posterior point at the midline on the tragus, $\mathrm{B}$; lateral canthus of the eye, $\mathrm{C}$; the most lateral point on the corner of the mouth, D; soft tissue pogonium which is the most prominent point at the midline on the chin and $\mathrm{E}$; most inferior point on the angle of the mandible. The 3 lines were $\mathrm{AC}, \mathrm{AD}$ and BE. A baseline measurement was carried out just before the surgery and similar measurements were carried out on days 2 (48 hours), 5 and 7 post surgery. The difference between the postoperative and preoperative measurements was calculated.

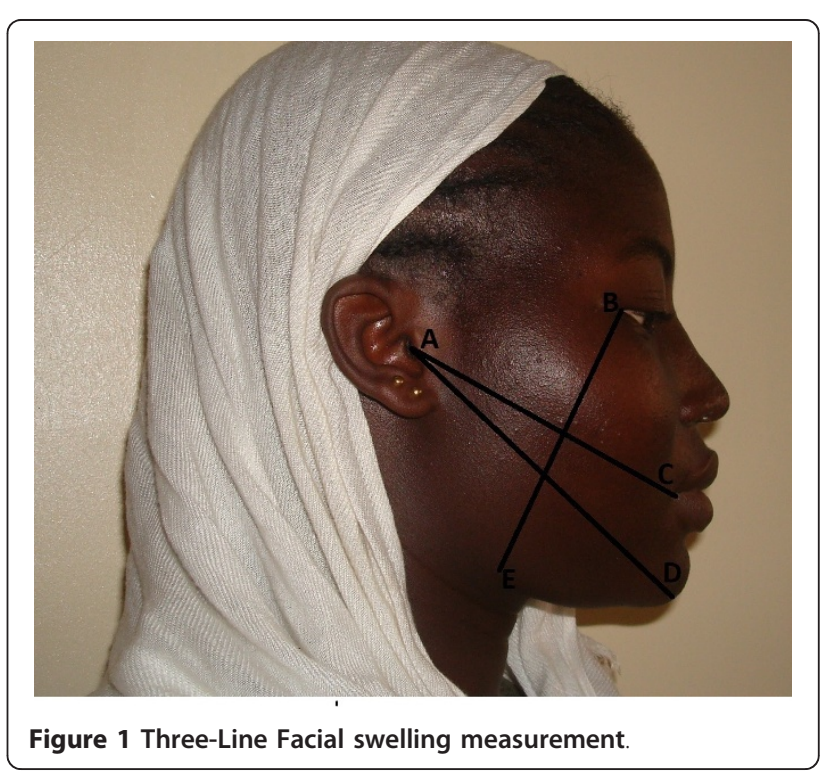


Maximum inter-incisal distance was used as the index of trismus using Boyle's gauge-a venier calibrated calliper. Percentage mouth opening was calculated on each postoperative review days. The measurement of MID was taken from the incisal edge of the upper right central incisor (or a prosthethic equivalent) to the incisal edge of the lower right central incisor. Three readings were taken for each patient and the average was determined. This constitutes the reading for the particular day. Baseline measurements were taken just before the surgery and similar readings were carried out on days 2 (48 hours), 5 and 7 postoperatively. Percentage mouth opening was calculated thus: postoperative minus preoperative measurement multiplied by 100 .

Data analysis was carried out with Statistical Package for Social Sciences (SPSS) 15.0 for Windows. A multivariate analysis of the effect of patients' age, sex, type of impaction and operative time on pain, swelling and trismus was also carried out. Mean values are presented with 95\% confidence interval.

\section{Results}

A total of 120 patients comprising 42 male and 78 females were studied.

The age range of the patients was 19 to 42 years with a mean (SD) age of 26.7 years. Fifty-eight (48.3\%) patients were in the age range of 19-26 years, fifty-three $(44.2 \%)$ were in the age range of 27-34 years and nine $(7.5 \%)$ were in the age range of $35-42$ years. The effect of age on pain, swelling and trismus is shown in Figure 2A, 2B and 2C. Patients in the age range of 35-42 years recorded a significantly lower pain score $(\mathrm{p}=0.5)$ compared with lower age groups on day 1 , but subsequently the pain recorded was significantly higher than that recorded for the lower age groups $(P=0.01,0.2$ on day 3 and 4 respectively). The mouth opening was much better in the lower age group on day 2 and $5(p=0.007$ and $\mathrm{p}=0.01$ respectively). There was a steady increase in the swelling recorded with increasing age but the difference in swelling between the age group ranges were not statistically significant.

The mean (SD) duration of operation was 22.63 (7.4) minutes with a range of 11 to 35 minutes. The distribution of operative time and its effect on postoperative pain, swelling and trismus is shown in tables 1 and 2 . The pain increased progressively with increasing operative time on day $1(\mathrm{p}=0.04)$. Even though the difference between the operative time ranges was not statistically significant, there was a progressive increase in swelling and trismus with increasing operative time.

The distribution of types of impaction and its effect on pain, swelling and trismus is shown in tables 3 and 4 . Distoangular impaction is significantly associated with higher VAS score on Day 1 and $2(p=0.01,0.004)$ when
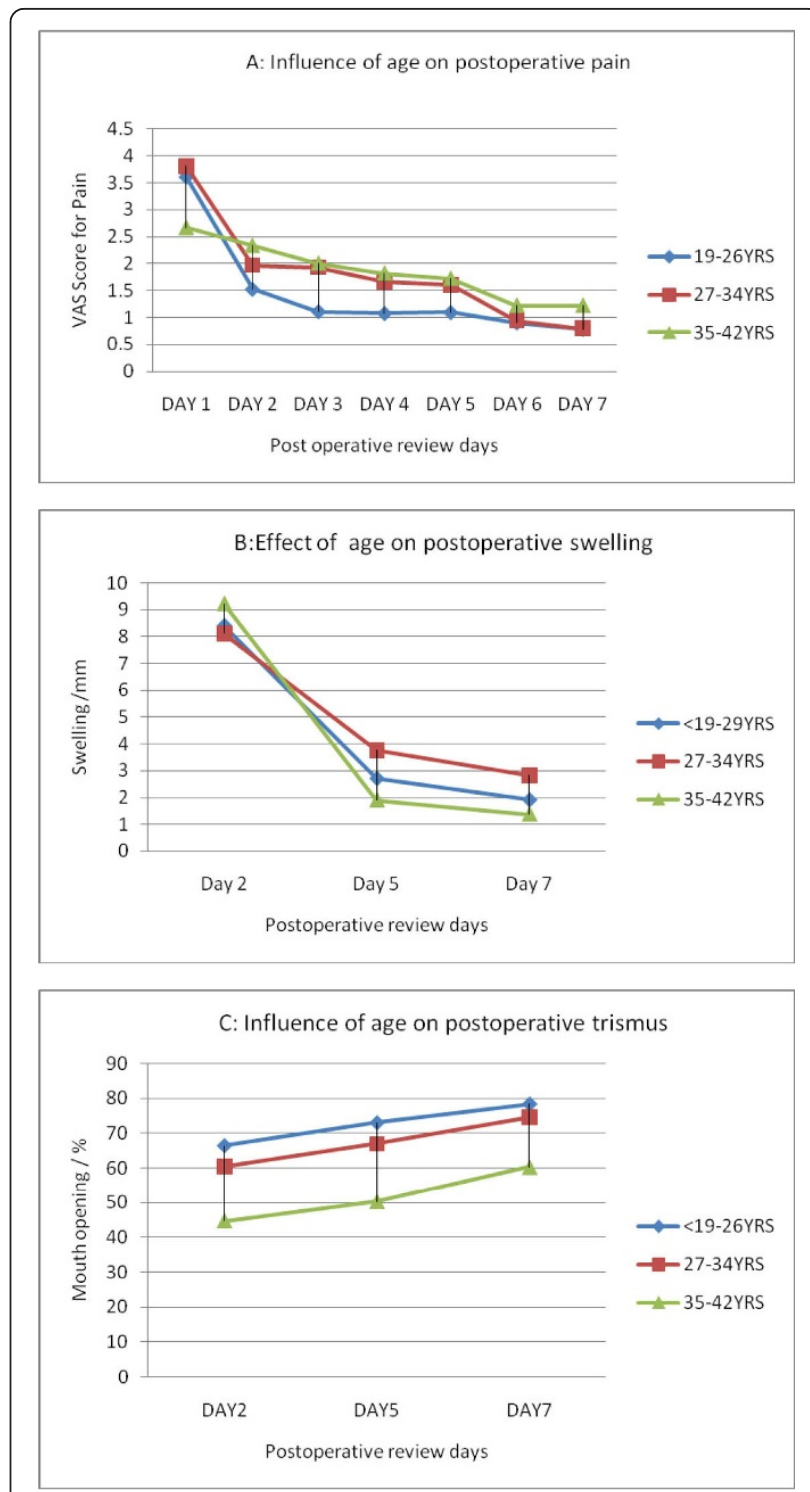

Figure 2 Effect of age on postoperative pain, swelling and trismus. A. Influence of age on Postoperative pain. B: Effect of age on Postoperative swelling. C: Influence of age on postoperative trismus.

compared with the other types of impaction. Distoangular and Horizontal impaction are associated with a higher degree of swelling $(\mathrm{p}=0.2,0.5$ and 0.0 on days 2,5 and 7 respectively), and reduced mouth opening ( $\mathrm{p}=0.0,0.0,0.0$ on days 2,5 and 7 respectively) on postoperative review days when compared with vertical and mesioangular impaction. Vertical impaction was associated with the least degree of facial swelling and best mouth opening among the types of impaction

A multivariate analysis of the effect of patients'age, sex, type of impaction and operative time on pain, swelling and trismus is shown in table 5. Using Pillai's 
Table 1 Influence of operative time on Postoperative pain

\begin{tabular}{|c|c|c|c|c|c|c|c|c|}
\hline \multicolumn{2}{|c|}{ Operative Time/Minutes } & \multicolumn{7}{|c|}{ VAS SCORE } \\
\hline & & DAY1 & DAY2 & DAY3 & DAY4 & DAY5 & DAY6 & DAY7 \\
\hline \multirow[t]{3}{*}{$\leq 17$} & Mean & 3.2667 & 1.6333 & 1.5000 & 1.2000 & .9333 & .7333 & .5333 \\
\hline & $\mathrm{N}$ & 30 & 30 & 30 & 30 & 30 & 30 & 30 \\
\hline & Std. Deviation & 1.22990 & 1.09807 & 1.13715 & .76112 & .52083 & .63968 & .50742 \\
\hline \multirow[t]{3}{*}{$18-23$} & Mean & 3.3784 & 2.1351 & 1.7838 & 1.7568 & 1.6757 & 1.1892 & .9459 \\
\hline & $\mathrm{N}$ & 37 & 37 & 37 & 37 & 37 & 37 & 37 \\
\hline & Std. Deviation & 1.55190 & 1.39766 & 1.22781 & 1.47959 & 1.56443 & 1.15079 & 1.02594 \\
\hline \multirow[t]{3}{*}{$24-29$} & Mean & 3.8421 & 1.2105 & 1.1053 & .9474 & 1.2105 & .4211 & .4211 \\
\hline & $\mathrm{N}$ & 19 & 19 & 19 & 19 & 19 & 19 & 19 \\
\hline & Std. Deviation & .83421 & 1.22832 & .56713 & .62126 & .78733 & .50726 & .50726 \\
\hline \multirow[t]{3}{*}{$30-35$} & Mean & 4.0882 & 1.8235 & 1.3824 & 1.2353 & 1.3529 & 1.1471 & 1.1471 \\
\hline & $\mathrm{N}$ & 34 & 34 & 34 & 34 & 34 & 34 & 34 \\
\hline & Std. Deviation & 1.23993 & 1.40282 & 1.45674 & 1.07475 & 1.17763 & .85749 & .85749 \\
\hline$P$ value & & 0.04 & 0.08 & 0.224 & .041 & .073 & .005 & .003 \\
\hline
\end{tabular}

Trace, patients'sex, with an eigen value of 0.65 , contributed least to the dependent variables of pain, swelling and trismus while operative time as a single factor, affected the dependent factors most with an eigenvalue of 1.46. Interaction of operative time and type of impaction had the highest eigenvalue of 2.66 compared to other factors matrix tests, indicating that the interactions of operative time and types of impaction affected swelling, trismus and pains observed in operated patients most. The significance of all the model matrixes $(p<0.5)$ is an indication that the effects of age, sex, type of impaction and operative on pain, swelling and trismus were not due to chance. However, Roy's largest root is equal to Hotelling's trace (0.352), in the case of operative time and sex interaction, which implies that sex effect does not contribute much to the output of variables of pain, swelling and trismus.

\section{Discussion}

Severity of pain, amount of swelling and degree of trismus are the primary indicators of patients discomfort following surgical extraction of an impacted third molar tooth [17].

This study recorded a significant influence of age on post operative morbidity following surgical extraction of impacted third molar teeth. A higher degree of trismus and facial swelling was recorded in patients with advancing age. This finding is in agreement with some studies $[15,18,19]$. Bruce et al, [15] while investigating the role of age on postoperative morbidity associated with mandibular third molar, found that patients above 35 years recorded more swelling and trismus. According to de Boer [18], older patients appeared to complain of more post operative symptoms after removal of their third molar than did young patient. The reason might be that

Table 2 Effect of operative time on postoperative swelling and trismus

\begin{tabular}{|c|c|c|c|c|c|c|c|}
\hline \multicolumn{2}{|c|}{ Operative Time/Minutes } & \multicolumn{3}{|c|}{ Swelling/mm } & \multicolumn{3}{|c|}{ Mouth Opening/\% } \\
\hline & & DAY2 & DAY5 & DAY7 & DAY2 & DAY5 & DAY7 \\
\hline \multirow[t]{3}{*}{$\leq 17$} & Mean & 6.8900 & 2.1500 & 1.4567 & 63.6450 & 72.1510 & 79.4743 \\
\hline & $\mathrm{N}$ & 30 & 30 & 30 & 30 & 30 & 30 \\
\hline & Std. Deviation & 5.72968 & 2.65664 & 2.70933 & 18.61544 & 22.43444 & 22.35302 \\
\hline \multirow[t]{3}{*}{$18-23$} & Mean & 7.6189 & 3.4541 & 2.6649 & 66.5241 & 73.4819 & 81.7759 \\
\hline & $\mathrm{N}$ & 37 & 37 & 37 & 37 & 37 & 37 \\
\hline & Std. Deviation & 4.37168 & 3.73189 & 3.55162 & 23.08559 & 22.64894 & 22.45892 \\
\hline \multirow[t]{3}{*}{$24-29$} & Mean & 9.9632 & 4.2316 & 3.0158 & 56.5837 & 61.1089 & 67.7526 \\
\hline & $\mathrm{N}$ & 19 & 19 & 19 & 19 & 19 & 19 \\
\hline & Std. Deviation & 7.65014 & 4.31110 & 2.75606 & 15.73888 & 17.23444 & 21.27848 \\
\hline \multirow[t]{3}{*}{$30-35$} & Mean & 9.5218 & 2.9853 & 2.1441 & 59.2153 & 64.4185 & 68.9188 \\
\hline & $\mathrm{N}$ & 34 & 34 & 34 & 34 & 34 & 34 \\
\hline & Std. Deviation & 7.63341 & 3.61605 & 2.51603 & 20.02752 & 21.30764 & 22.86510 \\
\hline P value & & .217 & .223 & .246 & 0.257 & 0.102 & .032 \\
\hline
\end{tabular}


Table 3 Relationship of type of impaction and postoperative pain

\begin{tabular}{|c|c|c|c|c|c|c|c|c|}
\hline \multirow{2}{*}{\multicolumn{2}{|c|}{ TYPE OF IMPACTION }} & \multicolumn{7}{|c|}{ VASUAL ANALOGUE SCALE SCORE } \\
\hline & & DAY1 & DAY2 & DAY3 & DAY4 & DAY5 & DAY6 & DAY7 \\
\hline \multirow[t]{3}{*}{$\mathrm{MA}$} & Mean & 3.3721 & 1.6744 & 1.4419 & 1.1163 & .9767 & .8372 & .6744 \\
\hline & N & 43 & 43 & 43 & 43 & 43 & 43 & 43 \\
\hline & Std. Deviation & 1.34560 & 1.04017 & .98325 & .76249 & .63577 & .65211 & .60635 \\
\hline \multirow[t]{3}{*}{ V } & Mean & 3.2174 & 1.7391 & 1.3913 & 1.3913 & 1.2174 & .8261 & .7826 \\
\hline & N & 23 & 23 & 23 & 23 & 23 & 23 & 23 \\
\hline & Std. Deviation & 1.44463 & 1.32175 & 1.43777 & 1.33958 & .99802 & 1.11405 & 1.12640 \\
\hline \multirow[t]{3}{*}{ DA } & Mean & 4.3333 & 2.5833 & 1.8750 & 1.6667 & 1.6667 & 1.1667 & 1.0417 \\
\hline & $\mathrm{N}$ & 24 & 24 & 24 & 24 & 24 & 24 & 24 \\
\hline & Std. Deviation & .81650 & 1.83958 & 1.51263 & 1.30773 & 1.09014 & 1.04950 & .85867 \\
\hline \multirow[t]{3}{*}{$\mathrm{H}$} & Mean & 3.7333 & 1.3000 & 1.3333 & 1.3667 & 1.6333 & 1.0000 & .8667 \\
\hline & N & 30 & 30 & 30 & 30 & 30 & 30 & 30 \\
\hline & Std. Deviation & 1.33735 & .91539 & 1.02833 & 1.21721 & 1.71169 & .94686 & .86037 \\
\hline$P$ value & & .011 & .004 & .372 & .289 & .041 & .475 & .380 \\
\hline
\end{tabular}

Key

$\overline{M A}-M e s i o a n g u l a r$, V-Vertical, DA-Distoangular, $\mathrm{H}$-Horizontal

erupted molars in older patient have been used for mastication and are therefore more tightly connected to the alveolar bone by the periodontal ligament which requires more aggression to remove. Third molar surgery result in physical injury to the tissues and are therefore followed by inflammatory reaction $[5,20]$. It has been proposed that following tissue injury or inflammation, there is a sequential release of mediators from mast cells, the vasculature and other cells. Histamine and serotonin appear first, followed shortly after by bradykinnin and later prostaglandins and other eicosanoids. Bradykinnin has been shown to produce pain in man when given intradermally, intraarterially or intraperitoneally and the hyperalgesia associated with prostaglandin is also due to its potentiation of Bradykinnin effect [20]. Postoperative swelling results from accumulation of protein rich exudates within the surrounding tissue and trismus occurred as a result of spasm of muscle fibres following inflammatory processes. These reactions (pain, swelling and trismus) may be a consequence of the formation of prostaglandins and other mediators of inflammation derived from membrane phospholipids, which are released following surgery [5]. Chiapasco et al [2] believe that the correlation between age and post operative complications might be related to increased bone density which may result in more manipulation during the operation.

This study recorded a lower score of pain perception in the older patient than the younger ones within the first 24 hours of surgery. Pain following third molar surgery has been shown to peak within 24 hours of surgery which has equally been confirmed with this study [4].

Table 4 Influence of type of impaction on postoperative swelling and Trismus

\begin{tabular}{|c|c|c|c|c|c|c|c|}
\hline \multirow[t]{2}{*}{ TYPE OF IMPACTION } & \multicolumn{4}{|c|}{ SWELLING/mm } & \multicolumn{3}{|c|}{ Mouth Opening/\% } \\
\hline & & DAY2 & DAY5 & DAY7 & DAY2 & DAY5 & DAY7 \\
\hline \multirow[t]{3}{*}{ Mesioangular } & Mean & 7.2372 & 2.6814 & .9070 & 59.4644 & 65.2314 & 71.4926 \\
\hline & $\mathrm{N}$ & 43 & 43 & 43 & 43 & 43 & 43 \\
\hline & Std. Deviation & 5.39210 & 3.21864 & 2juoop.04709 & 19.82389 & 22.11400 & 21.36244 \\
\hline \multirow[t]{3}{*}{ Vertical } & Mean & 6.3261 & 1.9478 & .7435 & 78.0052 & 84.9270 & 93.1578 \\
\hline & $\mathrm{N}$ & 23 & 23 & 23 & 23 & 23 & 23 \\
\hline & Std. Deviation & 6.06549 & 2.08324 & 1.54090 & 15.42520 & 15.00169 & 11.78812 \\
\hline \multirow[t]{3}{*}{ Distoangular } & Mean & 8.9475 & 3.2417 & 1.6750 & 56.1121 & 63.0758 & 69.7213 \\
\hline & $\mathrm{N}$ & 24 & 24 & 24 & 24 & 24 & 24 \\
\hline & Std. Deviation & 7.23615 & 4.03570 & 2.04605 & 17.48335 & 23.35297 & 25.98941 \\
\hline \multirow[t]{3}{*}{ Horizontal } & Mean & 11.0067 & 4.5433 & 4.0200 & 58.7123 & 65.4190 & 71.6787 \\
\hline & $\mathrm{N}$ & 30 & 30 & 30 & 30 & 30 & 30 \\
\hline & Std. Deviation & 6.41555 & 4.24408 & 3.50698 & 20.75739 & 19.14016 & 23.29330 \\
\hline$P$ value & & .026 & .047 & .000 & .000 & .001 & .000 \\
\hline
\end{tabular}


Table 5 Multivariate Tests of the effects of Operative time, Age range, Type of Impaction and Sex on swelling, Trismus and pain

\begin{tabular}{|c|c|c|c|c|c|c|c|}
\hline Factor & & Value & $\mathrm{F}$ & Hypothesis df & Error df & Sig. & Partial Eta Squared \\
\hline \multirow[t]{4}{*}{ Operative Time Range } & Pillai's Trace & 1.458 & 5.744 & 39.000 & 237.000 & .000 & .486 \\
\hline & Wilks' Lambda & .107 & 6.595 & 39.000 & 228.761 & .000 & .525 \\
\hline & Hotelling's Trace & 3.869 & 7.507 & 39.000 & 227.000 & .000 & .563 \\
\hline & Roy's Largest Root & 2.598 & 15.786(b) & 13.000 & 79.000 & .000 & .722 \\
\hline \multirow[t]{4}{*}{ Age Range } & Pillai's Trace & .938 & 5.296 & 26.000 & 156.000 & .000 & .469 \\
\hline & Wilks' Lambda & .213 & $6.901(\mathrm{a})$ & 26.000 & 154.000 & .000 & .538 \\
\hline & Hotelling's Trace & 2.980 & 8.711 & 26.000 & 152.000 & .000 & .598 \\
\hline & Roy's Largest Root & 2.720 & $16.320(b)$ & 13.000 & 78.000 & .000 & .731 \\
\hline \multirow[t]{4}{*}{ Type of Impaction } & Pillai's Trace & 1.075 & 3.395 & 39.000 & 237.000 & .000 & .358 \\
\hline & Wilks' Lambda & .211 & 4.054 & 39.000 & 228.761 & .000 & .405 \\
\hline & Hotelling's Trace & 2.489 & 4.829 & 39.000 & 227.000 & .000 & .453 \\
\hline & Roy's Largest Root & 1.923 & 11.688(b) & 13.000 & 79.000 & .000 & .658 \\
\hline \multirow[t]{4}{*}{ Sex } & Pillai's Trace & .646 & 10.786(a) & 13.000 & 77.000 & .000 & .646 \\
\hline & Wilks' Lambda & .354 & 10.786(a) & 13.000 & 77.000 & .000 & .646 \\
\hline & Hotelling's Trace & 1.821 & 10.786(a) & 13.000 & 77.000 & .000 & .646 \\
\hline & Roy's Largest Root & 1.821 & 10.786(a) & 13.000 & 77.000 & .000 & .646 \\
\hline \multirow[t]{4}{*}{ Operative Time Range * Age Range } & Pillai's Trace & .879 & 2.520 & 39.000 & 237.000 & .000 & .293 \\
\hline & Wilks' Lambda & .308 & 2.863 & 39.000 & 228.761 & .000 & .325 \\
\hline & Hotelling's Trace & 1.651 & 3.204 & 39.000 & 227.000 & .000 & .355 \\
\hline & Roy's Largest Root & 1.165 & $7.077(b)$ & 13.000 & 79.000 & .000 & .538 \\
\hline \multirow[t]{4}{*}{ Operative Time Range ${ }^{*}$ Type of Impaction } & Pillai's Trace & 2.655 & 5.008 & 78.000 & 492.000 & .000 & .443 \\
\hline & Wilks' Lambda & .009 & 7.520 & 78.000 & 430.658 & .000 & .546 \\
\hline & Hotelling's Trace & 12.894 & 12.453 & 78.000 & 452.000 & .000 & .682 \\
\hline & Roy's Largest Root & 9.324 & $58.815(b)$ & 13.000 & 82.000 & .000 & .903 \\
\hline \multirow[t]{4}{*}{ Age Range * Type of Impaction } & Pillai's Trace & .591 & 2.518 & 26.000 & 156.000 & .000 & .296 \\
\hline & Wilks' Lambda & .490 & 2.539(a) & 26.000 & 154.000 & .000 & .300 \\
\hline & Hotelling's Trace & .875 & 2.559 & 26.000 & 152.000 & .000 & .304 \\
\hline & Roy's Largest Root & .599 & $3.592(b)$ & 13.000 & 78.000 & .000 & .374 \\
\hline \multirow[t]{4}{*}{ Operative Time Range $*$ Sex } & Pillai's Trace & .261 & $2.087(\mathrm{a})$ & 13.000 & 77.000 & .024 & .261 \\
\hline & Wilks' Lambda & .739 & $2.087(\mathrm{a})$ & 13.000 & 77.000 & .024 & .261 \\
\hline & Hotelling's Trace & .352 & $2.087(\mathrm{a})$ & 13.000 & 77.000 & .024 & .261 \\
\hline & Roy's Largest Root & .352 & $2.087(\mathrm{a})$ & 13.000 & 77.000 & .024 & .261 \\
\hline \multirow[t]{4}{*}{ Type of Impaction * Sex } & Pillai's Trace & 1.303 & 11.205 & 26.000 & 156.000 & .000 & 651 \\
\hline & Wilks' Lambda & .111 & 11.875(a) & 26.000 & 154.000 & .000 & .667 \\
\hline & Hotelling's Trace & 4.298 & 12.562 & 26.000 & 152.000 & .000 & 682 \\
\hline & Roy's Largest Root & 3.090 & $18.540(b)$ & 13.000 & 78.000 & .000 & .756 \\
\hline
\end{tabular}

Pain is an unpleasant sensory and emotional experience associated with actual or potential tissue damage or described in terms of such damage [21]. Information about injury or the threat of injury (due to mechanical, thermal or chemical causes) is conveyed by a specialized set of peripheral nerve fibres termed 'nociceptors', which are mainly $\mathrm{A} \delta$ and $\mathrm{C}$ fibres. Interpretation of this information (impulse) in the central nervous system is affected by many factors including earlier experience, possible concomitant stimuli from other parts of the body and individual's pain threshold [22]. This makes perception of pain very complex and subjective. Hyperalgesia which follows tissue injury and inflammation following third molar surgery, is based at least in part, on sensitization of norciceptors, but age could be a factor in which older patients have higher threshold and hence lower pain score.

The mean operation time of 22.63 recorded in this study is similar to 21.92 and 25.0 mins reported by Raprastikul et al [17] and Saglam et al [23] respectively but at variance with 11.03 mins recorded by Lopez et al [24]. Variability of operation time could be due to surgeons experience, the definition of operation time and the need for extra attachments like tube drain during the operation. A steady increase in severity of pain, trismus and swelling was observed with increased operation 
time despite the fact that the difference was not statistically significant. In a study on a consecutive series of 104 patients, Garcia et al [4] reported a correlation between operation time duration and analgesic use over the first 48 hours post surgery. The same finding was also reported by Perderson et al [10] while investigating the interrelation of complaints after removal of impacted mandibular third molars. The duration of operation in the hand of a single surgeon could be a reflection of the difficulty and hence duration of tissue injury associated with the operation [25]. The longer the duration of tissue injury, the more the amount of mediators released and therefore could be a reflection of the severity of pain, swelling and trismus.

The commonest type of impaction, mesioangular $(\mathrm{n}=$ $43,35.8 \%$ ), recorded in this study is similar to the reports from earlier studies [26-28]. During normal development, the lower third molar begins its development in a horizontal angulation and as the jaw grows the angulation changes from horizontal to mesioangular then to vertical. Failure of rotation from the mesioangular to the vertical direction is the most common cause of a tooth becoming impacted [27]. Distoangular and horizontal type of impaction have been shown to be associated with higher degree of pain, swelling and trismus when compared with vertical and mesioangular type of impactions in this study. The type of impaction is an anatomical factor that determines the point of purchase (point of application of an elevator) and the extraction movements necessary to deliver a tooth during surgery [14]. The type of impaction gives a prediction of the difficulty of extraction and hence the severity of postoperative reactions. The difficulty reportedly encountered in decreasing order has been distoangular, horizontal, vertical and mesioangular [27]. Chiapasco et al [2] in their study reported $6.5 \%$ complication rate in association with distoangular impaction as opposed to $2.7 \%$ of vertical impaction. They concluded that this observation could be a reflection of surgical aggressiveness that is associated with this type of impaction.

\section{Conclusions}

The knowledge of the effect age, operation time and type of impaction on postoperative inflammatory reactions following third molar surgery is very important because it will assist in treatment planning. It could be used as an objective tool to educate patients on the need for early extraction of an impacted third molar to minimize postoperative morbidity. The type of impaction is developmental and cannot be controlled but the knowledge could assist in objective education of patients on possible postoperative reactions for medico- legal reasons.

\section{Authors Information}

Seidu Adebayo Bello, BDS, FMCDS, FWACS, Wasiu Lanre Adeyemo, BDS, FMCDS, FWACS, Dr. Med. Dent., FICS

Babatunde Olamide Bamgbose, BDS, FMCDS

Emeka Vitalis Obi, BDS

Ademola A Adeyinka BDS

\section{Acknowledgements}

I hereby acknowledge Mr Jayeoba O.J. of the department of agronomy, Faculty of agriculture, Nasarawa State University, for his contribution to the statistical analysis. The logistic support received from the administrative department of State House Medical Centre towards the success of the study, is also acknowledged.

\section{Author details}

'Department of Dental \& Maxillofacial Surgery, State House Medical Centre, Asokoro, Abuja, Nigeria. ${ }^{2}$ Department of Oral and Maxillofacial Surgery, Lagos University Teaching Hospital, Lagos, Nigeria. ${ }^{3}$ College of Dentistry, University of Nebraska Medical Center, Lincoln, Nebraska, USA.

\section{Authors' contributions}

$S A B$ conceived of the study on third molar surgery, participated in its design and coordination and helped to draft the manuscript. EVO and AAA made substantial contributions to the design, acquisition of data and manuscript drafting. WLA and BOB participated in data analysis, interpretation and critical review of intellectual content. All authors read and approved the final manuscript.

\section{Competing interests}

The authors declare that they have no competing interests.

Received: 21 September 2010 Accepted: 28 April 2011 Published: 28 April 2011

\section{References}

1. Ruta DA, Bissias E, Ogston S, Ogden GR: Assessing health outcomes after extraction of third molars: the postoperative symptoms severity (PoSSe) scale. Br J Oral Maxillofac Surg 2000, 38:480-487.

2. Chiapasco M, De Cicco L, Marroneh K: Side effects and complications associated with third molar surgery. Oral Surg Oral Med Oral Pathol 1993, 76:412-420.

3. Lopes V, Mumenya R, Feinmann C, Harris M: Third molar surgery: An audit of the indications for surgery, post operative complaints and patient satisfaction. Br J Oral Maxillofac Surg 1995, 33:33-35.

4. Garcia GA, Sampedro FH, Rey JH, Torreira MG: Trismus and pain after removal of impacted lower third molars. J Oral Maxillofac Surg 1997, 55:1223-1226.

5. Schultze-mosgau S, Schmelzeisen JC, Frolich JC, Schmele H: Use of ibuprofen and methylprednisolone for the prevention of pain and swelling after removal of impacted third molars. J Oral Maxillofac Surg 1995, 53:2-7.

6. Bui Chi H, Seldin EB, Dodson TB: Types, frequencies and risk factors for complications after third molar extraction. J Oral Maxillofac Surg 2003, 61:1379-1389

7. Reuton T, Smeeton N, Mcurk M: Factors predictive of difficulty of mandibular third molar surgery. Br Dent J 2001, 190:607-610.

8. Gaya MVO, Capilla MV, Mateos RG: Relation of patient and surgical variables to postoperative pain and inflammation in the extraction of third molars. Medicinal Oral 2002, 7:360-369.

9. Jerjes W, El-Maaytah M, Swinson B, Banu B, Upile T, et al: Expe-rience versus complication rate in third molar surgery. Head and Face Medicine 2006, 2:14, Available on med.com/2/1/14[Accessed 11th Feb, 2010].

10. Pederson A: Inter-relationship of complaints after removal of impacted third molars. Int J Oral Maxillofac Surg 1985, 14:241-247.

11. Winter GB: Principles of exodontias as applied to the impacted third molar $1^{\text {st }}$ ed. St. Louis American medical books 1926. In Contemporary 
Oral and Maxillofacial Sugery.. 2 edition. Edited by: Peterson $\sqcup$, Ellis E, Hupp JR, Tucker MR. Mosby, St Louis; 1993:225-260.

12. Albert DGM, Gomes ACA, Vasconcelos BCE, Silva EDO, Hollanda GZ: Comparison of orthopantomographs and conventional tomo-graphy images for assessing the relationship between impacted lower third molars and the mandibular canal. J Oral Maxillofac Surg 2006, 64:1030-1037.

13. Pell GJ, Gregory BT: Impacted mandibular third molars: classification and modified techniques for removal. Dental Digest 1933, 19:430, Obiechina AE. Update in the technique of third molar surgery. Ann of Ibadan Postgrad Med 2003, 1 40-45.

14. Gbotolorun OM, Arotiba GT, Ladeinde AL: Assessment of factors associated with surgical difficulty in impacted mandibular third molar extraction. J Oral Maxillofac Surg 2007, 65:1977-1983.

15. Bruce RA, Frederickson GC, Small GS: Age of patients and morbidity associated with mandibular third molar surgery. J Am Dent Assoc 1980, 101:240-244.

16. Akinwande JA: Mandibular third molar impaction-A comparison of two methods for predicting surgical difficulty. Nig Dent J 1991, 10(1):3-7.

17. Rakprasitkul S, Pairuchives V: Mandibular third molar surgery with primary closure and tubedrain. Int J Oral Maxillofac Surg 1997, 26:187-190.

18. de Boer M, Raghoebar GM, Stegenga B, Schoen PJ, Boering G: Complications after mandibular third molar extraction. Quitessence Int 1995, 26:779-784.

19. Capuzzi P, Montebugnoli L, Vaccaro MA: Extraction of impacted third molars, a longitudinal prospective study on factors that affect postoperative recovery. Oral Surg Oral Med Oral Pathol 1994, 77:341-343.

20. Cotran RS, Kumar V, Collins T: Robbins Pathologic basis of disease. W.B. Sanders Company, Philadephia; 6 1999, 50-87.

21. Seymour RA, Meechan JG, Blair GS: An investigation into post operative pain after third molar surgery under local analgesia. Br J Oral Maxillofac Surg 1985, 23:410-415.

22. Haefeli M, Elfering A: Pain assessment. Eur Spine J 2006, 15:S17-S24.

23. Saglam AA: Effect of tube drain with primary closure technique on postoperative trismus and swelling after removal of fully impacted mandibular third molars. Quintessence Int 2003, 34:143-147.

24. Lopez-Carriches C, Rafael GF, Jose MM, Manuel DF: Influence of smoking upon the post operative course of lower third molar surgery. Med Oral Pathol Oral Cir Bucal 2006, 11:56-60.

25. Benediktsdottir IE, Wenzel A, Petersen JK, Hintze H: Mandibular third molar removal: risk indicators for extended operation time, post operative pain and complication. Oral Surg Oral Med Oral Pathol 2004, 79:438-446.

26. Quek SL, Tay CK, Tay KH, Toh SL, Lim KC: Pattern of third molar impaction in a Singapore Chinese population: a retrospective radiographic survey. Int J Oral Maxillofac Surg 2003, 32:548-552.

27. Peterson LJ, Ellis E, Hupp JR, Tucker MR: Contemporary Oral and Maxillofacial sugery. Mosby, St Louis; 2 1993, 225-260.

28. Saheeb BDO, Obuekwe ON: An audit of mandibular third molar surgery. Nig J Surg Research 2001, 3(2):66-74.

doi:10.1186/1746-160X-7-8

Cite this article as: Bello et al: Effect of age, impaction types and operative time on inflammatory tissue reactions following lower third molar surgery. Head \& Face Medicine 2011 7:8.

\section{Submit your next manuscript to BioMed Central and take full advantage of:}

- Convenient online submission

- Thorough peer review

- No space constraints or color figure charges

- Immediate publication on acceptance

- Inclusion in PubMed, CAS, Scopus and Google Scholar

- Research which is freely available for redistribution 